\title{
Analysis of road safety incentives in highway concessions in Spain
}

\section{Análisis de los incentivos de seguridad vial en las concesiones de carreteras en España}

Rangel, T. - Vassallo, J.M. - Arenas, B.

\begin{abstract}
Public Private Partnerships (PPPs) are mostly implemented for three reasons: to circumvent budgetary constraints, encourage efficiency and improvement of quality in the provision of public infrastructure. One of the ways of reaching the latter objective is by the introduction of performance-based standards tied to bonuses and penalties to reward or punish the performance of the contractor. These performance based standards often refer to different aspects such as technical, environmental and safety issues.
\end{abstract}


This paper focuses on the implementation of safety based incentives in PPPs. The main aim of this paper is to analyze whether the incentives to improve road safety in PPPs are effective in improving safety ratios in Spain. To this end, negative binomial regression models have been applied using information from the Spanish high capacity network in 2006.

The findings indicate that even though road safety is highly influenced by variables that are not much controllable by the contractor such as the Average Annual Daily Traffic and the percentage of heavy vehicles in the highway, the implementation of safety incentives in PPPs has a positive influence in the reduction of fatalities, injuries and accidents.

Keywords: Public Private Partnerships, performance-based quality standards, road safety.

Resumen: Las asociaciones público-privadas (APP) se ejecutan sobre todo por tres razones: para eludir las restricciones presupuestarias, fomentar la eficiencia y la mejora de la calidad en la provisión de infraestructura pública. Una de las maneras de alcanzar este último objetivo es mediante la introducción de normas basadas en el rendimiento vinculados a las bonificaciones y penalizaciones para premiar o castigar el desempeño del contratista. Estos estándares basados en el desempeño a menudo se refieren a diferentes aspectos como los problemas técnicos, ambientales y de seguridad.

Este documento se centra en la aplicación de incentivos basados en la seguridad de las APP. El objetivo principal de este trabajo es analizar si los incentivos para mejorar la seguridad vial en las APP son eficaces en la mejora de relaciones de seguridad en España. Para ello, los modelos de regresión binomial negativa se han aplicado con la información de la red española de alta capacidad en 2006. 
Los resultados indican que a pesar de que la seguridad vial está muy influenciada por variables que no son controlables tanto por el contratista como por el Tráfico medio diario anual y el porcentaje de vehículos pesados en la autopista, la aplicación de incentivos de seguridad en las APP tiene una influencia positiva en la reducción de las muertes, lesiones y accidentes.

Palabras clave: Asociaciones público-privadas, normas de calidad basadas en el rendimiento, seguridad vial.

\section{Introduction}

Public Private Partnerships (PPPs) are mostly implemented to circumvent budgetary constraints, and to encourage efficiency and quality in the provision of public infrastructure in order to reach social welfare. One of the ways of reaching the latter objective is by the introduction of performance based standards tied to bonuses and penalties to reward or punish the performance of the contractor.

One of the most common ways of implementing PPPs in managing infrastructure is through the concession approach, which consists basically in transferring final design, construction, maintenance, and operation of the infrastructure to a private consortium, in exchange for which that consortium receives the right to charge a fee to the user or to the government on behalf of the user, for a period of time contractually agreed in advance (Vassallo and Gallego, 2005).

One of the key aspects of PPPs is to encourage the private sector to manage and operate the infrastructure in the best way. To that end, 
in the last few years, PPPs are evolving from mere demand-based contracts (when the revenues of the contractor are related to the traffic demand) to performance-based contracts referred to different aspects such as availability, congestion, state of the pavement, safety, and so on. Consequently, the revenues of the contractor tend to depend more and more to the quality of the services rather than on traffic demand (Harding et al., 2010).

Two reasons lie behind this trend. First, PPP contractors can manage better the service performance they offer than the traffic flows in the infrastructure. And second, by encouraging the PPP contractors to provide a better service, by aligning the social and the private benefits, they will end up producing a more efficient outcome for society.

Traditionally, most of the infrastructure management contracts, including PPPs, had not introduced explicit incentives to improve quality. However, nowadays most PPP contracts are encouraging the introduction of incentives to foster the contractor to provide an optimal quality level. In this way, the contracts incorporate a set of standards that the contractor must fulfill. If the contractor fails to comply with these requirements, the public authority will penalize the contractor or even rescind the contract.

This approach has moved many countries to introduce performance based indicators tied to bonuses and penalties in their PPP contracts. Some countries such as United Kingdom, Finland, Portugal and Spain have introduced these kind of incentives. 
Those performance-based incentives, however, have to be introduced in the right way in PPP contracts. To that end, the marginal reward to the contractor for reaching a certain quality level should never be larger than the marginal social benefit produced at that level. The contractor will provide a quality level at the point where the marginal revenue obtained due to a certain quality increase equals its marginal cost. If the incentives are defined this way, the contractor will be encouraged to provide the best service compatible with its production costs (Vassallo, 2007).

The aim of this paper is to identify whether the incentives to improve road safety in PPPs are ultimately effective in improving safety ratios with an empirical analysis for the case of Spain. The results show that there are more fatalities, injuries and accidents on road segments without incentives when they are compared with other segments with incentives.

The paper is divided in seven sections. After this introduction, we describe the experience in the introduction of safety incentives in highway PPPs across Europe. In the third section, we describe the characteristics of the highway network in Spain. In the fourth section, we show a literature review of the models explaining the variables influencing road safety ratios. In the fifth section, we explain the data sources used for the empirical analysis. In the sixth section, we develop the methodology and explain the results obtained. In the last section, we remark the main conclusions and further research. 


\section{Analysis of experiences in the introduction of road safety incentives in Europe}

Europe is the world's region with the greater tradition of incorporating performance-based incentives in PPPs. There are few countries with PPP roads that introduce positive incentives based on explicit road safety indicators. These countries where this was done, it became a normal practice and the latest PPP contracts continue to introduce and improve these incentives. This happens in Spain, Finland, Hungary, Norway, Portugal and United Kingdom. Italy introduced price-caps tied to road safety indicators in such a way that the concessionaire is allowed to set higher tolls if the safety ratios are better. In Ireland, PPP road contracts include some road safety indicators but they do not provide bonuses. In other countries, like Denmark, the Netherlands and Belgium, there are new and sophisticated PPP contracts, but they do not have positive incentives based on explicit road safety indicators.

The design of the road safety indicators is quite heterogeneous across different countries. There are differences both in the variable adopted to measure the outcome and in the final formula employed. Most of the PPPs include number of injuries, number of fatalities or a combination of number of light accidents, serious accidents and fatal accidents to build the indicator.

On the other hand, including the exposure to the risk (expressed by traffic) is a generalized practice. Very often, the initial accident data is divided by the annual traffic, usually measured in terms of millions or billions of vehicles-kilometers. E18 road (Muurla-Lohja) in Finland, the M6 road in Hungary, several PPPs in Portugal (the IP-4, for instance) and the latest PPP roads awarded in Spain use this methodology. The advantage of introducing the exposure to the risk (traffic) explicitly is that distortions in road safety results are reduced. 
With the same aim, in many other PPP contracts the assessment of the indicator is done by comparing similar roads, in terms of traffic, number of carriageways, etc. With this methodology it is possible to control the global evolution of casualties by many factors, most of them not manageable by the road operator. Some road contracts where the indicator is set in this way are E-18 road (Grimstad - Kristiansand) in Norway, the latest PPP roads awarded in the United Kingdom (for example, A1 \& M25) and some PPP roads in Spain (like the M-407 highway).

Regarding the way of rewarding or penalizing the contractor, it was identified two trends: incentives related to the extension of the deadline of the project, and incentives related to increase the fee to be paid to the PPP contractor.

\section{Characteristics of highways in Spain}

Spain has extensive experience in managing and financing highways through public-private-partnerships (PPPs). Most of the PPPs have been put into effect through concession contracts that have a long tradition in Spanish administrative law. Most of the highway concessions awarded in Spain have been toll highways. However, in the last few years, there was a large increase in the number of other PPP approaches, such as shadow-toll or performance-based contracts.

Three different periods regarding the implementation of highway concessions in Spain can be identified: from 1967 to 1975, from 1976 to 1995, and from 1996 to the present. Between 1967 and $1975,2,042 \mathrm{~km}$ of toll highways were granted by the central government of Spain. The results of the implementation of concession contracts in Spain during this period were rather controversial. On the one hand, highway concessions achieved the goal of providing the country with a modern highway network at a time when the public budget of Spain was not sufficient to afford such a huge cost. 
On the other hand, the guarantees made by the government to facilitate concessions' funding over time became very costly for the country (Izquierdo and Vassallo, 2004).

The second stage of highway concessions is from 1976 to 1995. In this period, no highway concessions were awarded. There were several reasons for this. First, the two petroleum crises in the 1970s destabilized the Spanish economy. Second, after Franco's death, the political atmosphere in Spain was uncertain. Third, and most important, the Socialist government, which took office in 1982 and remained until 1996, was politically opposed to promoting private concessions as a means to finance highways. Instead, the socialist government opted for modernizing the Spanish road network by widening and upgrading the most important roads, turning them into dual-roadway fast lanes. These free highways were called "autovias".

The term "autovias" was used in Spain in the early years of $80 \mathrm{~s}$ for identifying any free highway with physically separated lanes in each direction. The first autovias in Spain were built by doubling lanes out of single carriageways. The design standards of these highways (known as first generation autovias) had design standards well below those of the toll highways.

Since 2000 , the quality standards in the construction of autovias improved notably to make comparable with toll highways. These are called second generation autovias. There is no technical difference between second generation autovias and toll highways. The first generation autovías and second generation autovias were built, funded and managed by the Spanish government. None of the public highways (autovias) has economic incentives to improve road safety though the government is committed to building and maintaining the autovías with socially expected quality standards.

The third stage began in 1996 and continues into the present. In 1996, the conservative Popular Party took office in Spain. The need 
to contain Spain's public deficit was the most difficult challenge facing the new government. This was the main reason why the new government decided to implement once again the policy of offering concessions so as to encourage the participation of the private sector in financing new transportation infrastructure. From 1996 to now, 1,003 kilometers of new toll highway concessions have been awarded by the central government of Spain through this approach. Another novelty of the period since 1996 is that not only the Spanish central government, but also the regional and even the local governments have started using the concession approach to implement both toll and shadow-toll highways.

The Spanish high capacity network in 2006 is presented in Figure 1.

Most of the PPPs implemented in the last stage include a provision to extend the contract duration up to four years if several performance-based indicators tied to quality aspects like queuing in toll plazas, congestion, state of the pavement, safety, and satisfaction of the users are ultimately fulfilled. Other PPP's awarded recently in Spain also include incentives in terms of annual bonuses to be incorporated to the periodic fee paid by the government to the contactor.

Regarding safety, the PPP contractor can be granted an extension of the contract if safety indicators remain below an accident benchmark for similar roads. To that propose the government measures in a yearly basis the Risk Index (RI) and Mortality Index (MI) of the highways and compare it with other highways with similar characteristics in terms of alignment and traffic flow. 


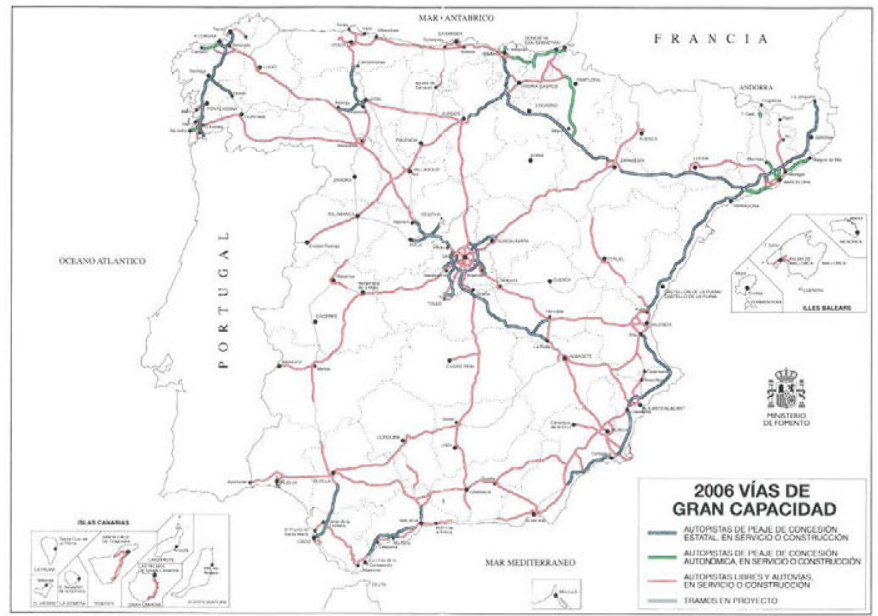

Figure 1. 2006 Spanish high capacity network. Source: Ministerio de Fomento (2007)

\section{Models that explain road safety: a literature review}

This paper analyzes whether the incentives to improve road safety in PPPs are effective. The statistical models most commonly used to explain the relationship between motor vehicle accidents and a set of predictor variables are the Poisson and NB regression models (Miaou and Lum, 1993; Noland and Oh, 2004; Chang, 2005; Caliendo et al., 2007).

From an empirical stand-point, the relationship between accident frequency and traffic flows can be found in Jovanis and Chang (1986), Abdel-Aty and Essam Radwan (2000) and Persaud et al. (2000); and the relationship between accident rate and traffic flow can be found in Vitaliano and Held (1991) and Hauer and Bamfo (1997). The relationship between accident frequency or accident rate and traffic flows show a great variation in theirs results. 
Jovanis and Chang (1986), Abdel-Aty and Essam Radwan (2000) and Persaud et al. (2000) point out that accident frequency increases with Average Annual Daily Traffic (AADT). On the other hand, Vitaliano and Held (1991) cannot detect any significant increase in the accident rate when AADT increases. According to Hauer and Bamfo (1997) the accident rate even decreases with an increasing AADT.

Few studies have analyzed the effect of heterogeneous flows, and specifically the effect that the presence of heavy good vehicles (HGVs) in the traffic flow has on accidents. Hiselius (2004) analyzed the relationship between accident frequency and traffic flow in four different road types according to speed limit and road width in two conditions: homogenous and heterogeneous traffic. The results show that the expected number of accidents increases less than proportionally with the traffic flow, in the homogenous case. For the heterogeneous case, the expected number of accidents decreases with increasing number of trucks. According to Arenas et al. (2009), the expected number of accident increases with the addition of one vehicle in AADT, and increases with one additional HGV when comparing high capacity roads to single carriageway roads.

Other studies have been carried out to establish relationships between accidents and the frequency of intersections (Ivan and O'Mara, 1997), environmental factor (Fridstrom et al., 1995; Shankar et al., 1995; Chang, 2005; Caliendo et al., 2007), geometric infrastructure characteristics (Hauer, 2004; Chang, 2005), number of lanes (Milton and Mannering, 1998; Noland and Oh, 2004), and speed limits (Fridstrøm et al., 1995; Ossiander and Cummings, 2002). In this paper, Poisson and negative binomial (NB) regression models were applied to know the relationship between safety incentives and road safety in Spain. This paper focuses on variables related to traffic flow, infrastructure characteristics (intersections), road operation and incentives given to the PPP contractors. The authors have not found any empirical study about safety incentives offered to the PPP contractors. 


\section{Data for the case of Spain}

The models that were calibrated in this paper cover the year 2006. We chose this year because it is the most recent year where a complete database is available.

The data used for the empirical model came from two different sources: police-reported accident data supplied by the Ministry of Internal Affairs (Ministerio del Interior, 2006) and traffic data supplied by the Ministry of Public Works (Ministerio de Fomento, 2006). Using these databases it was necessary to build the final database combining both accident data and traffic data. The population for the models were made up of road stretches of the Spanish highcapacity network both PPP highways (toll highways) and public highways (autovias).

Some exogenous variables that may potentially influence safety and do not depend on the concessionaire's ability to manage the road were selected. These are: continuous variables such as (1) Average annual daily traffic (AADT), (2) Percentage of heavy goods vehicles (\%HGV) and (3) Number of intersections for each stretch (INT) and two selected variables that may explain any relation between PPPs and accidents, (4) Road operation (RO) and (5) Incentives (INC). Furthermore, in order to fit the model it was considered the vehicle exposure (vk). It was measured in millions of vehiclekilometers as vk $\mathrm{j}_{\mathrm{j}}=365 \mathrm{l}_{\mathrm{j}} \mathrm{AADT}_{\mathrm{j}} / 106$, where $\mathrm{AADT}_{\mathrm{j}}$ and $\mathrm{l}_{\mathrm{j}}$ are respectively the average annual daily traffic and length $(\mathrm{km})$ of road section $\mathrm{j}$ obtained from traffic database.

The number of intersections for each stretch (INT) introduced as discrete value with 2 levels (it takes 1 for stretches with at least 1 intersection and it takes 0 otherwise) was obtained from the Geographic Information System (GIS), the analyses was performed using ArcGis 9.2. Each stretch of the sample was analyzed using the GIS application to count the number of intersections. 
Data for Road operation ( $\mathrm{RO}$ ), introduced in models as categorical variable, was obtained from the Traffic map 2006 (Ministry of Public Works). The roadway segmentation is defined by the Ministry of Public Works (Ministerio de Fomento, 2006b), which can be for the case of the Spanish high capacity network: second generation autovias (AV), first generation autovias (1AV) or toll highways (TH). TH are PPPs, AV and $1 \mathrm{AV}$ are public highways.

To know which segments had road safety incentives (INC) it was analyzed each concession contract in force in 2006. The first Spanish concession contract awarded with implementation of road safety incentives was in 2002. All of the contracts from 2002 to 2006 were analyzed. INC is a discrete variable with 2 levels (it takes 1 for stretches with safety incentives and it takes 0 otherwise).

For this study, the dependent variables are the fatal, injury and accident rates. 1,042 road segments were extracted out of a total of 6,293 from the 2006 traffic map, after selection criteria based on complete information for traffic flow and infrastructure variables. It was considered stretches with and without accidents to avoid selection bias. The study includes PPPs (toll highways) and public highways (first and second generation autovias). For this study was considered only stretches of the Spanish Interurban Road State Network. The final data base represents $62 \%$ of the total Spanish highcapacity network. The total number of segments (with and without accidents) and the length by road operation are presented in Table 1. The percentages in the table are by column. 


\begin{tabular}{|c|c|c|c|c|c|c|c|}
\hline \multirow{3}{*}{$\begin{array}{c}\text { Road } \\
\text { operation }\end{array}$} & \multicolumn{6}{|c|}{ Segments } & \multirow{3}{*}{$\begin{array}{l}\text { Length } \\
\text { (km) }\end{array}$} \\
\hline & \multicolumn{3}{|c|}{$\mathrm{N}^{\circ}$} & \multicolumn{3}{|c|}{$\%$} & \\
\hline & $\begin{array}{l}\text { with ac- } \\
\text { cidents }\end{array}$ & $\begin{array}{l}\text { Without } \\
\text { accidents }\end{array}$ & Total & $\begin{array}{c}\text { With } \\
\text { accidents }\end{array}$ & $\begin{array}{l}\text { Without } \\
\text { accidents }\end{array}$ & Total & \\
\hline AV & 275 & 287 & 562 & 26.39 & 27.54 & 53.93 & $3,790.46$ \\
\hline $1 \mathrm{AV}$ & 43 & 266 & 309 & 4.13 & 25.53 & 29.66 & $2,285.02$ \\
\hline TH & 60 & 111 & 171 & 5.76 & 10.65 & 16.41 & $1,372.24$ \\
\hline Total & 378 & 664 & 1,042 & 36.28 & 63.72 & 100 & $7,447.72$ \\
\hline
\end{tabular}

Table 1: Road segment data.

The descriptive statistics are represented in Table 2. The descriptive statistics indicate that the mean traffic intensity (AADT) is higher on IAV than AV and TH. The low traffic intensity in TH could be explained because the users pay tolls.

There is more heavy good vehicles traffic in public highways (AV and 1AV) than PPPs (TH). The range and the standard deviation in $\mathrm{AV}$ and $\mathrm{AV}$ are higher than $\mathrm{TH}$, which indicates more heterogeneity in traffic flow. 


\begin{tabular}{|c|c|c|c|c|c|c|}
\hline Variables & $\begin{array}{c}\text { Road } \\
\text { operation }\end{array}$ & Mean & S.D. & Range & Minimum & Maximum \\
\hline \multirow{4}{*}{ AADT } & AV & $23,686.04$ & $21,875.96$ & $139,040.00$ & $1,270.00$ & $140,310.00$ \\
\hline & IAV & $35,735.05$ & $34,262.09$ & $186,365.00$ & $5,135.00$ & $191,5000.00$ \\
\hline & $\mathrm{TH}$ & $16,508.43$ & $12,950.00$ & $58,093.00$ & $1,094.00$ & $59,187.00$ \\
\hline & Total & $26,080.92$ & $26,046.31$ & $190,406.00$ & $1,094.00$ & $191,500.00$ \\
\hline \multirow{4}{*}{$\% H G V$} & AV & 18.53 & 10.12 & 72.40 & 2.80 & 75.20 \\
\hline & IAV & 23.37 & 8.95 & 48.10 & 4.60 & 52.70 \\
\hline & TH & 10.35 & 5.39 & 32.60 & 1.50 & 34.10 \\
\hline & Total & 18.63 & 10.08 & 73.70 & 1.50 & 75.20 \\
\hline \multirow{4}{*}{ INT } & AV & 2.08 & 1.21 & 8.00 & 0.00 & 8.00 \\
\hline & IAV & 2.38 & 1.59 & 12.00 & 0.00 & 12.00 \\
\hline & $\mathrm{TH}$ & 1.54 & 0.70 & 3.00 & 0.00 & 3.00 \\
\hline & Total & 2.08 & 1.29 & 12.00 & 0.00 & 12.00 \\
\hline \multirow{4}{*}{$\mathbf{v k}$} & AV & 52.28 & 56.22 & 451.28 & 0.42 & 451.70 \\
\hline & IAV & 79.25 & 70.65 & 355.89 & 3.13 & 359.02 \\
\hline & TH & 42.51 & 42.91 & 250.19 & 0.48 & 250.67 \\
\hline & Total & 58.68 & 60.60 & 451.28 & 0.42 & 451.70 \\
\hline
\end{tabular}

Table 2: Descriptive statistics by road operation and total. Year 2006. 


\section{Methodology and results}

Poisson and NB regressions were applied to determine the relationship between fatalities, injuries and accidents and traffic variables, number of intersections for each stretch, road operation and road safety incentives offered to the concessionaire. In this work the response variables are number of fatalities, injuries and accidents.

The Poisson overdispersion parameter indicates that the data may be overdispersed. When Pearson's chi-square divided by the degrees of freedom is greater than 1, the data may be overdispersed, otherwise the data may be underdispersed. All Poisson models presented Value/df greater than 1, therefore it was necessary to test the NB as an alternative model, which enables the variance of the dependent variable to differ from its mean.

The accident rate of the j segment $\left(\lambda_{\mathrm{j}}\right)$ is defined as the expected number of accidents $\left(E\left[Y_{j}\right]\right)$ per million-vehicle $\mathrm{km}$. Therefore the regression model is then expressed as $\mathrm{E}\left[\mathrm{Y}_{\mathrm{j}}\right]=\lambda_{\mathrm{j}} \mathrm{v}$, using the log-link function to relate the response to the linear predictor.

The general expression for the estimated model is:

$$
\widehat{\mathrm{E}\left[Y_{1]}\right]}=\exp \left(\widehat{\beta_{0}}+\sum_{m=1}^{M} \hat{\beta}_{m} X_{m j}+\hat{\beta}_{v} \ln v k_{j}\right)
$$

With the restriction $\hat{\beta}_{v}=1$

The accident rate is expressed as:

$$
\hat{\lambda}_{i j}=\frac{\widehat{\mathrm{E}\left[Y_{1 \mathrm{~J}}\right]}}{\mathrm{vk}_{\mathrm{j}}}
$$

Table 3 summarizes the estimated NB regressions. Each column refers to a model with the endogenous variables and every row 
to exogenous variables. There is an estimated parameters for each variable. The significance of coefficients was checked using Wald statistic (in bracket), which rejects the null hypothesis that the coefficient is zero with a level of $95 \%$ confidence. Different goodness-of-fit statistics were used to select the model such as deviance, log-likelihood and Pearson chi-square statistics. Other measures were also evaluated such as Akaike Information Criterion (AIC) (Akaike, 1974) and the Bayesian Information Criterion (BIC) (Schwarz, 1978).

A criterion for variables inclusion was used by testing the likelihood ratio (LR). In addition, the correlation coefficient between them was prevented.

After analyzing Tables 3, it could highlight the following results:

1. $\log (\mathrm{AADT})$ is statistically significant for the fatality, injury and accident rates. The coefficient signs are negative for all models (fatalities, injuries and accidents), suggesting that a greater AADT is associated with lower rates for fatalities, injuries and accidents. This result confirms the hypothesis proposed by Vitaliano and Held (1991) and Hauer and Bamfo (1997) that accident rates decrease when AADT increases.

2. $\log (\% \mathrm{HGV})$ was found to be statistically significant for injury and accident models. The coefficient signs are negative for all models. This means that the larger the percentage of heavy good vehicles the smaller the injury and accident rates. This could be related to the speed reduction that heavy vehicles impose to light vehicles on the traffic flow. This result is in line with Hiselius (2004), if this analysis was in terms of number of accidents.

3. INC variable showed the expected negative sign, suggesting that establishing incentives in the PPP contracts is associated with lower rates for fatalities, injuries and accidents. The 
coefficient signs do not change in all models. This variable was found to be statistically significant for injury and accident models.

4. The INT (intersection) variable showed the expected positive signs suggesting that the increased number of intersections is associated with the increased level of fatalities, injuries and accidents. There are more fatalities, injuries and accidents in stretches with at least one intersection than stretches without intersections. However, this variable was found to be statistically insignificant.

The main reason for the insignificance of INT in the models could be that the kind of roads used for the analysis does not have at grade intersections which are those that most affect road safety. The Spanish high capacity network only has grade-separated intersections. These types of intersections reduce the accident potential due to vertical separation of traffic. This result is in line with the findings of Ivan and O'Mara (1997).

5. RO indicates that there is a differentiated behavior among toll highways, second generation autovias and first generation autovías.

Toll highways (TH) showed the expected negative sign in all models suggesting that there are fewer fatalities, injuries and accidents in toll highways compared to $\mathrm{AV}$, which is the reference class. In other words, toll highways managed and operated by the private sector turn out to be safer that free highways managed and operated by the public sector.

The only odd result that was found in the analysis is that the variable $1 \mathrm{AV}$ has an unexpected negative sign suggesting that $1 \mathrm{AV}$ has fewer fatalities, injuries and accidents compared to AV. This result is strange because, as mentioned earlier in this paper, first generation autovias (1AV) have poorer design standards than second generation autovias (AV). 
The main reason for that is that first generation autovias are among the busiest highways in Spain in terms of traffic so the AADT in these highways is often close to their capacity and consequently the speed of the flow is lower, which improves safety ratios.

\begin{tabular}{|c|c|c|c|c|c|}
\hline Variables & $\begin{array}{c}\text { Measurement } \\
\text { level }\end{array}$ & & Fatalities & Injuries & Accidents \\
\hline \multirow{2}{*}{ Intercept } & & & 0.936 & 0.334 & -0.677 \\
\hline & & & $(0.403)$ & (0.269) & (0.947) \\
\hline \multirow{2}{*}{$\log (A A D T)$} & \multirow{2}{*}{ S } & & $-0.700 a$ & $-0.157 a$ & $-0.106 b$ \\
\hline & & & $(37.977)$ & $(10.016)$ & $(4.031)$ \\
\hline \multirow{2}{*}{$\log (\% H G V)$} & \multirow{2}{*}{ S } & & -0.084 & $-0.470 a$ & $-0.507 a$ \\
\hline & & & $(0.236)$ & $(37.863)$ & $(37.781)$ \\
\hline \multirow{2}{*}{ INC } & \multirow{2}{*}{ C } & \multirow{2}{*}{$\begin{array}{l}\text { stretch with } \\
\text { incentives }\end{array}$} & -0.818 & $-0.676 c$ & $-0.943 b$ \\
\hline & & & (0.552) & $(2.670)$ & (3.946) \\
\hline \multirow{2}{*}{ INT } & \multirow{2}{*}{ S } & & 0.817 & 0.125 & 0.167 \\
\hline & & & $(2.360)$ & (0.629) & $(0.880)$ \\
\hline \multirow{4}{*}{$\begin{array}{c}\text { Road } \\
\text { operation }\end{array}$} & \multirow{4}{*}{ C } & \multirow{2}{*}{ TH } & -0.461 & $-0.398 a$ & $-0.351 a$ \\
\hline & & & (2.954) & (1 1.809) & (7.562) \\
\hline & & \multirow{2}{*}{ IAV } & $-0.511 b$ & $-0.405 a$ & $-0.423 a$ \\
\hline & & & (6.545) & $(23.900)$ & $(22.610)$ \\
\hline $\log (v k)$ & S & & 1 & 1 & 1 \\
\hline \multicolumn{2}{|c|}{ Deviance (Dp) } & & 579.862 & $2,562.148$ & $1,933.346$ \\
\hline \multicolumn{2}{|c|}{ Pearson Chi-Square (X2) } & & $1,669.727$ & $4,202.451$ & $2,784.678$ \\
\hline \multicolumn{2}{|c|}{ Log Likelihood } & & -486.091 & $-2,462.047$ & $-1,978.212$ \\
\hline \multicolumn{2}{|c|}{ AIC } & & 986.183 & $4,938.093$ & $3,970.424$ \\
\hline \multicolumn{2}{|c|}{$\mathrm{BIC}$} & & $1,021.121$ & $4,973.032$ & $4,005.362$ \\
\hline \multicolumn{2}{|c|}{ Overdispersion parameter $(k)$} & & 1.546 & 3.891 & 2.578 \\
\hline
\end{tabular}

Measure level: Scale (S), Categorical (C) ${ }^{a} p<0.01,{ }^{b} p<0.05,{ }^{c} p<0.10$

Table 3: Negative binomial regression models for fatalitites, injuries and accidents. 
The expressions of fatality, injury and accident rates for different road operations can be determined by the parameters estimated in Table 3. As one example, the equations of toll highways by segment (j) in specific scenarios are:

Toll highways segments with incentives - without intersection:

$$
\hat{\lambda}_{T M_{j}}=0.139(\overline{A A D T})^{-0.106}(\overline{\% H G V})^{-0.507}=0.015
$$

Toll highways segments with incentives - at least 1 intersection:

$$
\hat{\lambda}_{T M_{j}}=0.164(\overline{A A D T})^{-0.106}(\overline{\% H G V})^{-0.507}=0.018
$$

Toll highways segments without incentives -without intersection:

$$
\hat{\lambda}_{T M_{j}}=0.357(\overline{A A D T})^{-0.106}(\overline{\% H G V})^{-0.507}=0.040
$$

Toll highways segments without incentives - at least 1 intersection:

$$
\hat{\lambda}_{T M_{j}}=0.423(\overline{A A D T})^{-0.106}(\overline{\% H G V})^{-0.507}=0.046
$$

From these expressions it can observe clearly that the incentives given to the concessionaires have a positive impact on reducing accident rates. For stretches without intersection, the number of accidents per 1 million vehicle-kilometers is about 2.66 times higher in toll highways without incentives compared to toll highways with incentives. And, for stretches with at least 1 intersection, the number of accidents per 1 million vehicle-kilometers is about 2.55 times higher in toll highways without incentives compared to toll highways with incentives 


\section{Conclusions and future research}

The main conclusions of this paper are the following:

- Some variables such as the AADT and the \%HGV, which are not manageable by the contractor, are the most significant predictors of fatalities, injuries and accidents.

- The INC variable was found to be statistically significant in the injury and accident model. However, if incentives have an impact on the frequency of road accidents, they have an impact on fatalities as well, because of the negative sign in fatal models. If incentives given to the concessionaires avoid accidents, they avoid fatalities which are a consequence of accidents. The results indicate that incentives have an influence on road safety, there are more fatalities, injuries and accidents on road segments without incentives than in road segments with incentives. This fact demonstrates that the implementation of road safety incentives in PPP contracts is effective to encourage the contractor to adopt the measures that he can handles to improve road safety standards.

- The results indicate the need for further research. First, the analysis of the size of the economic incentive set up in the PPP contract on the ultimate improvement of safety ratios is a crucial aspect. Second, it would be useful to analyze the evolution of safety performance over the years in PPP highways with safety-based incentives. Third, a cross-cutting comparison of the different types of incentives (incentives related to the deadline of the project vs incentives related to payments) would be of the greatest interest. 


\section{References}

ABDEL-ATY, M.A., ESSAM RADWAN, E.A. (2000). Modeling traffic accident occurrence and involvement. Accident Analysis and Prevention, 32, pp. 633-642.

AKAIKE, H. (1974). A new look at the statistical model identification. IEEE Transaction on Automatic Control, 19, pp. 716-723.

ARENAS, B., APARICIO, F., GONZÁLEZ, C., GÓMEZ, A. (2009). The influence of heavy good vehicle traffic on accidents on different types of Spanish interurban roads. Accident Analysis and Prevention, 41, pp. 15-24.

CHANG, L.Y. (2005). Analysis of freeway accident frequencies: negative binomial regression versus artificial neural network. Safety Science, 43 , pp. 541-557.

CALIENDO, C., GUIDA, M., PARISI, A. (2007). A crash-prediction model for multilane roads. Accident Analysis and Prevention, 39, pp. 657-670.

FRIDSTRØM, L., IFVER, J., INGEBRIGTSEN, S., KUMALA, R., KROGSGARD THOMSEN, L. (1995). Measuring the contribution of randomness, exposure, weather, and daylight to the variation in road accident counts. Accident Analysis and Prevention, 27, pp. 1-20.

GRIMSEY, D., LEWIS, M. (2005). Are Public Private Partnerships value for money? Evaluating alternative approaches and comparing academic and practitioner views. Accounting Forum, 29, pp. 345-378.

HARDING, J., BODARWÉ, H., ČADEŽ, I. (2010). Evaluation of availability and service performance based payment mechanisms for PPP Road Traffic Infrastructure Projects. Transportation Research Board, Washington, D.C. 
HAUER, E. (2004). Safety models for urban four lane undivided road segments. Transportation Research Board $N^{o}$ 985901, TRB. Washington D.C, pp. 96-105.

HAUER, E., BAMFO, J. (1997). Two tools for find what function links the dependent variable to the explanatory variables. In Proceedings of the ICTCT Conference. Lund.

HISELIUS, L.W. (2004). Estimating the relationship between accident frequency and homogeneous and inhomogeneous traffic flows. Accident Analysis and Prevention, 36, pp. 985-992.

IVAN, J., O'MARA, P. (1997). Prediction of traffic accident rates using Poisson regression. 76th Annual Meeting of the Transportation Research Board $\mathrm{N}^{\circ}$ 970861, Washington, D.C.

IZQUIERDO, R. AND VASSALLO, J.M. (2004). Nuevos sistemas de gestión y financiación de infraestructuras de transporte. Colegio de Ingenieros de Caminos, Canales y Puertos. Madrid.

JOVANIS, P., CHANG, H. (1986). Modeling the relationship of accident to mile travelled. Transportation Research Record N ${ }^{\mathrm{D}} 1068$. TRB. National Research Council, Washington DC., pp. 42-51.

MIAOU, S.P., LUM, H. (1993). Modeling vehicle accidents and highway geometric design relationships. Accident Analysis and Prevention, 25, pp. 689-709.

MINISTERIO DE FOMENTO (2006). Mapa de Tráfico 2006. Dirección General de Carreteras, Madrid, España.

MINISTERIO DE FOMENTO (2007). Informe 2007 sobre el sector de autopistas de peaje en España. Delegación del Gobierno en las Sociedades Concesionarias de Autopistas Nacionales de Peaje, España.

MINISTERIO DEL INTERIOR (2006). Base de datos de accidentes. Dirección General de Tráfico, España. 
MILTON, J., MANNERING, F. (1998). The relationship among highway geometrics, traffic-related elements and motor vehicle accident frequencies. Transportation, 25, pp. 395-413.

NOLAND, R.B., OH, L. (2004). The effect of infrastructure and demographic change on traffic-related fatalities and crashes: a case study of Illinois county-level data. Accident Analysis and Prevention, 36, pp. $525-532$.

OSSIANDER, E.M., CUMMINGS, P. (2002). Freeway speed limits and traffic fatalities in Washington State. Accident Analysis and Prevention, 34, pp. 13-18.

PERSAUD, B., RETTING, R. A., LYON, C. (2000). Guidelines for identification of hazardous highway curves. Transportation Research Record $\mathrm{N}^{\mathrm{o}} 1717$, pp. 14-18.

SCHWARZ, G. (1978). Estimating the dimension of a model. The Annals of Statistics 6, pp. 461-464.

SHANKAR, V., MANNERING, F., BARFIELD, W. (1995). Effect of roadway geometrics and environmental factors on rural freeway accidents frequencies. Accident Analysis and Prevention, 27, pp. 371-389.

VASSALLO, J.M. AND GALLEGO, J. (2005). Risk-sharing in the New Public Works Concession Law in Spain. Transportation Research Record $\mathrm{N}^{\mathrm{o}}$ 1932. TRB, National Research Council, Washington, DC, pp. 1-8.

VASSALLO, J.M. (2007). Implementation of quality criteria in tendering and regulating infrastructure management contracts. Journal of Construction Engineering and Management, 133, pp. 553-561.

VITALIANO, D.F., HELD, J. (1991). Road accident external effects: an empirical assessment. Applied Economics, 23, pp. 373-378.

ZLATOPHER, T. (1988). Testing for functional form and autocorrelation in the analysis of motor vehicle deaths. Q. Rev. Econ. Business, 27 , pp. 6-17. 